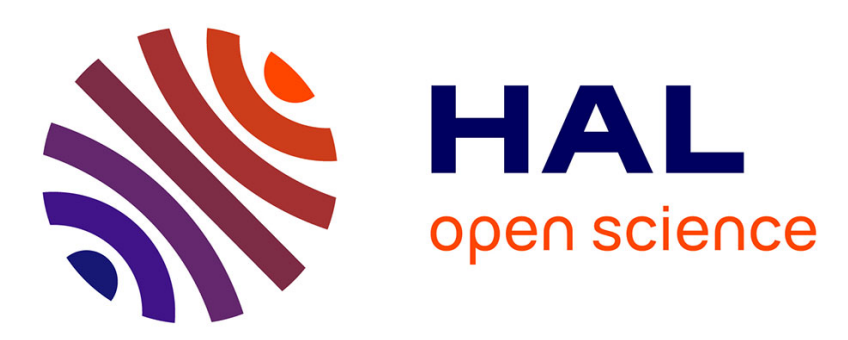

\title{
Interactions between lactic and propionic acid bacteria
} Pg Piveteau, S Condon, Tm Cogan

\section{To cite this version:}

Pg Piveteau, S Condon, Tm Cogan. Interactions between lactic and propionic acid bacteria. Le Lait, 1995, 75 (4_5), pp.331-343. hal-00929441

\section{HAL Id: hal-00929441 https://hal.science/hal-00929441}

Submitted on 1 Jan 1995

HAL is a multi-disciplinary open access archive for the deposit and dissemination of scientific research documents, whether they are published or not. The documents may come from teaching and research institutions in France or abroad, or from public or private research centers.
L'archive ouverte pluridisciplinaire HAL, est destinée au dépôt et à la diffusion de documents scientifiques de niveau recherche, publiés ou non, émanant des établissements d'enseignement et de recherche français ou étrangers, des laboratoires publics ou privés. 


\title{
Original article
}

\section{Interactions between lactic and propionic acid bacteria}

\author{
PG Piveteau 1, S Condon 1, TM Cogan 2 \\ 1 Department of Microbiology, University College, Cork; \\ 2 National Dairy Products Centre, Teagasc, Fermoy, Ireland
}

\begin{abstract}
Summary - In some cheeses, propionic acid bacteria (PAB) ferment lactate to propionate, acetate and $\mathrm{CO}_{2}$, which are important in determining the flavour and texture of the cheese. Interactions between 14 strains of lactic acid bacteria (LAB) (Lactobacillus helveticus, $L b$ acidophilus, $L b$ lactis, Streptococcus thermophilus and Lactococcus lactis) and 4 strains of PAB (Propionibacterium freudenreichii and $P$ acidipropionici) were studied in whey. Stimulation or inhibition was judged by the effect on growth rate and final cell mass $\left(O D_{600}\right)$. No inhibition of growth was found. The growth of all 4 strains of PAB was stimulated by $L b$ helveticus and Str thermophilus. The degree of stimulation of the PAB by the other $L A B$ varied. In control and $L b$ helveticus $R R$ whey, $L$ lactate was used preferentially over $D$ lactate by $P$ freudenreichii KM. $L b$ helveticus RR increased the levels of amino acids and peptides in the whey. All of the amino acids, except threonine and cysteine, and some of the peptides were used during subsequent growth of $P$ freudenreichii $\mathrm{KM}$. The addition of aspartate stimulated growth of $P$ freudenreichii $\mathrm{KM}$ in control whey and reduced the amount of lactate converted to propionate, but not acetate. The stimulant(s) was stable to heating to $121^{\circ} \mathrm{C}$ for $15 \mathrm{~min}$ and eluted in several peaks after chromatography on Sephadex G-25. Ultrafiltration resulted in a total loss of activity.
\end{abstract}

interaction / propionic acid bacteria / lactic acid bacteria / whey / growth

Résumé - Interactions entre bactéries lactiques et bactéries propioniques. Dans certains types de fromage, les bactéries propioniques (PAB) fermentent le lactate en propionate, acétate et $\mathrm{CO}_{2}$, produits importants pour la saveur et la texture de ces fromages. Les interactions entre 14 souches de bactéries lactiques ( $L A B$ ) Ractobacillus helveticus, Lb acidophilus, Lb lactis, Streptococcus thermophilus et Lactococcus lactis) et 4 souches de PAB (Propionibacterium freudenreichii et $\mathrm{P}$ acidipropionici) ont été étudiées en milieu lactosérum. La stimulation ou l'inhibition étaient jugées en fonction du taux de croissance et de la masse cellulaire $\left(D_{600}\right)$ en fin de fermentation. Aucune inhibition de la croissance n'a été observée. La croissance des 4 souches de PAB était stimulée par Lb helveticus et Str thermophilus. La stimulation des $P A B$ par les autres $L A B$ était variable. Dans le lactosérum produit par $\mathrm{Lb}$ helveticus $R R$ et dans le contrôle, l'isomère $L$ de l'acide lactique était utilisé par la souche de $P$ freudenreichii $K M$ de façon préférentielle par rapport à lisomère $D$. L'ajout d'aspartate stimulait la croissance de $\mathrm{P}$ freudenreichii $\mathrm{KM}$ dans le lactosérum controle, et réduisait la proportion de lactate convertie 
en propionate sans changer celle convertie en acétate. Le(s) stimulant(s) résistaient au chauffage à $121^{\circ} \mathrm{C}$ pendant 15 min et formait plusieurs pics après chromatographie sur Sephadex G-25. L'ultrafiltration résultait en une perte d'activité.

\section{interaction / bactérie propionique / bactérie lactique / lactosérum / croissance}

\section{INTRODUCTION}

Cheese is a complex biological system which undergoes numerous biochemical changes during manufacture and ripening. In Swiss-type cheese manufacture, thermophilic lactic acid bacteria (LAB), including Lactobacillus helveticus, Lactobacillus delbrueckii subsp lactis and Streptococcus thermophilus, are used as starters and degrade lactose to $D$ and $L$ lactate. Propionibacteria $(P A B)$ then metabolize lactate to propionate, acetate and $\mathrm{CO}_{2}$ during the extended ripening (Hettinga and Reinbold, 1972; Langsrud and Reinbold, 1973). The propionic acid fermentation is critical to the final quality of the cheese as $\mathrm{CO}_{2}$ is responsible for eye formation, while propionic acid contributes to the development of the typical nutty flavour (Gautier et al, 1993). The quality of the cheese, therefore, depends on the extent of the lactic acid fermentation and the propionic acid fermentation. Different isomers of lactate are produced by the starter LAB. Lactobacillus delbrueckii subsp lactis produces D lactate, Streptococcus thermophilus produces $\mathrm{L}$ lactate and Lactobacillus helveticus produces a mixture of $D$ and $L$ lactate. Some strains of $P A B$ have a preference for the $\mathrm{L}$ isomer (Crow, 1986a); however, the interaction between the 2 fermentations is not limited to lactate production and utilization. Interactions between $\mathrm{LAB}$ and $\mathrm{PAB}$ have been reported in co-cultures (Lee et al, 1976; Parker and Moon, 1982; Perez Chaia et al, 1987) and in sequential cultures (Hunter and Frazier, 1961; Czarnocka-Roczniakowa et al, 1972). The compounds involved in these interactions have not been identified. The object of this study was to characterize the interactions between $P A B$ and $L A B$ more fully.

\section{MATERIALS AND METHODS}

\section{Organisms and medium}

Three strains of Lactobacillus helveticus (RR, 303, 3321), 1 strain of Lactobacillus delbrueckii subsp lactis (LL51), 1 strain of Lactobacillus acidophilus (LbA), 5 strains of Streptococcus thermophilus (1781, 1821, 1842, STB01 and STB02), 4 strains of Lactococcus lactis (C10, ML8, E8 and AM2), 1 strain of Propionibacterium acidipropionici (L5) and 3 strains of Propionibacterium freudenreichii ( $\mathrm{T}, \mathrm{KM}$ and $\mathrm{H}$ ) were used. All strains were from our culture collection except STB01 and STB02 (Chr Hansen Laboratories, Cork, Ireland) and LL51 (Institut Technique du Gruyère, Rennes, France). PAB were routinely transferred weekly in sodium lactate broth (SLB) and stored at $4^{\circ} \mathrm{C}$. $L A B$ were stored at $-80^{\circ} \mathrm{C}$ and subcultured at least twice in $10 \%(\mathrm{w} / \mathrm{v})$ sterile reconstituted skim milk (RSM) before use. The composition of SLB was $1 \%(\mathrm{w} / \mathrm{v})$ tryptone, $1 \%(\mathrm{~W} / \mathrm{v})$ yeast extract, $0.5 \%(\mathrm{w} / \mathrm{v}) \mathrm{KH}_{2} \mathrm{PO}_{4}$ and $1 \%(\mathrm{w} / \mathrm{v}) \mathrm{D} / \mathrm{L}$ sodium lactate, $\mathrm{pH} 6.5$.

\section{Whey production}

Interactions were studied by growing $\mathrm{PAB}$ in filtersterilized whey obtained after growth of the $L A B$ in RSM. Assessment of the $L A B / P A B$ interaction was done by comparing growth rates and final $O D$ at $600 \mathrm{~nm}$ in the starter whey to those in a control whey. A strain of $L A B$ was incubated at $42^{\circ} \mathrm{C}$ (thermophilic strains) or $30^{\circ} \mathrm{C}$ (mesophilic strains) for $24 \mathrm{~h}$ in RSM. The coagulated milk was centrifuged $\left(8000 \mathrm{~g}, 10 \mathrm{~min}, 4^{\circ} \mathrm{C}\right)$; the supernatant was adjusted to $\mathrm{pH} 6.0$ with $\mathrm{NaOH}(2 \mathrm{~N})$ 
and incubated for $30 \mathrm{~min}$ at $45^{\circ} \mathrm{C}$ to allow any precipitation to occur. This overcame subsequent precipitation of colloidal $\mathrm{Ca}$ salts during growth of the PAB. After a second centrifugation $(8000 \mathrm{~g}$, $30 \mathrm{~min}, 4^{\circ} \mathrm{C}$ ), the supernatant was filtered (Whatman $\left.n^{\circ} 1\right)$ and filter sterilized $(0.45 \mu \mathrm{m})$. Control whey was produced by acidifying RSM with $1 \%$ $(w / v)$ of a $50 \%$ mixture of $D$ and $L$ lactic acid. The coagulated milk was then processed as just described. Sterile wheys were stored at $4^{\circ} \mathrm{C}$ until required.

\section{Growth conditions}

The $P A B$ were grown in SLB for $3 \mathrm{~d}$ at $30^{\circ} \mathrm{C}$, centrifuged, washed with sterile $1 / 4$ strength Ringer's solution and resuspended in the original volume of Ringer's solution. Whey was inoculated ( $1 \%$, $\mathrm{v} / \mathrm{v}$ ) and dispensed in $10 \mathrm{ml}$ tubes, which were incubated under static conditions at $30^{\circ} \mathrm{C}$. Growth was followed by measuring $O D$ at $600 \mathrm{~nm}$. When the OD was greater than 0.5 , the culture was diluted before reading to maintain linearity between OD and cell mass. Two $\mathrm{ml}$ of culture was centrifuged and the supernatant frozen for further analysis. Purity of cultures was checked by microscopic examination throughout growth and by plating aerobically and anaerobically, at $30^{\circ} \mathrm{C}$, at the end of fermentation on sodium lactate agar (SLA).

\section{Analytical methods}

Lactose, glucose, galactose, lactate, propionate, acetate and succinate were quantified by highperformance liquid chromatography (HPLC) (column Aminex HPX $87 \mathrm{X}$ at $60^{\circ} \mathrm{C}$ and eluted with $0.04 \mathrm{~N} \mathrm{H}_{2} \mathrm{SO}_{4}$ ). $\mathrm{D}$ and $\mathrm{L}$ lactate were determined with enzymatic kits (Boehringer Mannheim). Amino acids were measured on a $120 \times 4 \mathrm{~mm}$ cation exchange column ( $\mathrm{Na}^{+}$form) using a Beckman 6300 amino acids Analyser (Beckman Instruments Ltd, High Wycombe, UK). The results were processed with a PC Minichrom. Peptide profiles were determined by reverse-phase HPLC (Shimadzu HPLC system, C8 Nucleosil wide pore column; solvent gradient: $A: 0.1 \%[w / v]$ trifluoroacetic acid, B: $0.1 \%[w / v]$ trifluoroacetic acid in acetonitrile).

\section{Heat treatment}

Starter whey, adjusted to $\mathrm{pH} 6.0$, was pasteurized $\left(63.5^{\circ} \mathrm{C}, 30 \mathrm{~min}\right)$ or autoclaved at $121^{\circ} \mathrm{C}$ for $15 \mathrm{~min}$. After treatment, the whey was centrifuged $\left(8000 \mathrm{~g}, 10 \mathrm{~min}, 4^{\circ} \mathrm{C}\right.$ ) and its $\mathrm{pH}$ readjusted to 6.0 before filter sterilization $(0.45 \mu \mathrm{m})$.

\section{Ultrafiltration}

Starter whey was ultrafiltered (Minitan system, Millipore) using a 10000 cutoff polysulfone filter (10 000 NMWL plates) until a 10-fold concentration of retentate was achieved.

\section{Perchloric acid extraction}

Perchloric acid was added to the starter whey to a final concentration of $2 \mathrm{~N}$. The mixture was centrifuged $\left(5000 \mathrm{~g}, 10 \mathrm{~min}, 4^{\circ} \mathrm{C}\right)$; the supernatant was neutralized with $\mathrm{KHCO}_{3}$, recentrifuged and the $\mathrm{pH}$ adjusted to 6.0 before filter sterilization. The original starter whey was diluted 2.5 -fold by this procedure.

\section{Gel filtration}

A $100 \mathrm{ml}$ Sephadex $\mathrm{G} 25$ column was equilibrated for $24 \mathrm{~h}$ at room temperature with distilled water. Five $\mathrm{ml}$ of starter whey was applied and the column eluted with distilled water at a flow rate of $20 \mathrm{ml} / \mathrm{h}$. Three $\mathrm{ml}$ fractions were collected and their A280 determined using the first fraction as a blank. Fractions forming a peak on the chromatogram were combined, freeze-dried, dissolved in $5 \mathrm{ml}$ of distilled water, filter sterilized and assayed for growth stimulation of the PAB cultures in control whey after $72 \mathrm{~h}$ of incubation.

\section{RESULTS}

The influence of the 14 strains of $L A B$ on the growth of $P$ freudenreichii KM is shown in figure 1. All strains of $L A B$, except $L c$ lactis $\mathrm{E} 8$, stimulated the growth rate and final 

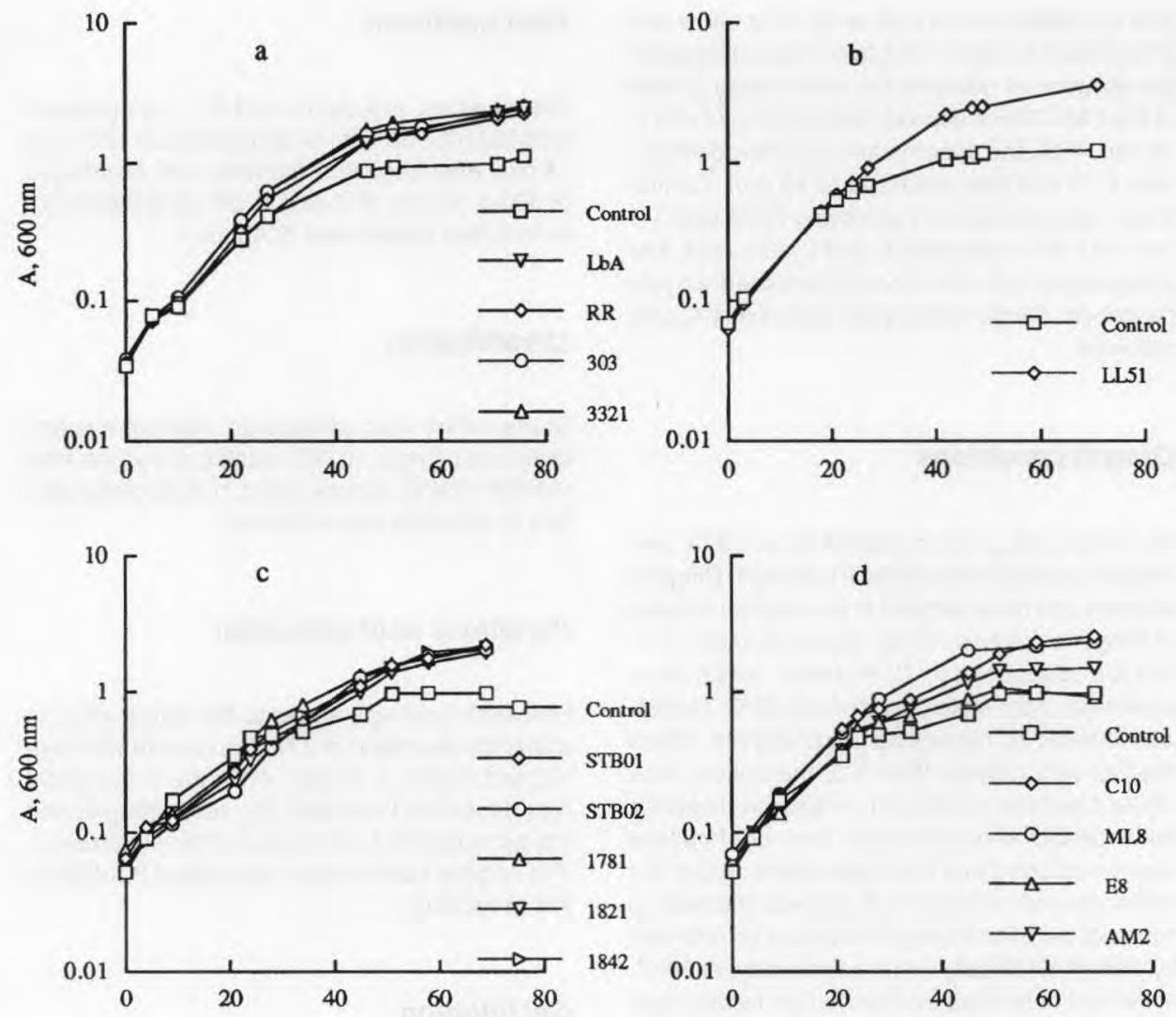

Time, h

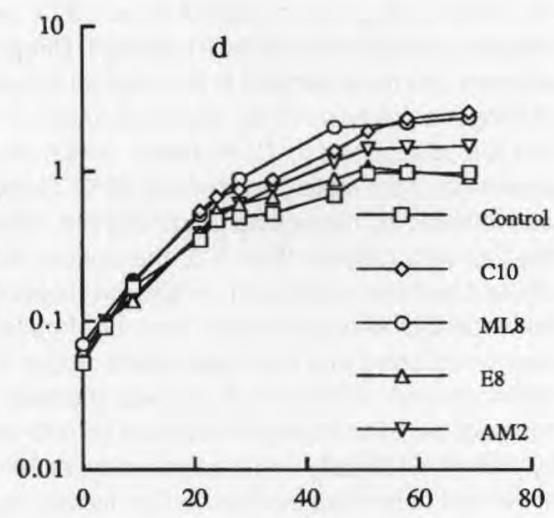

Time, h

Fig 1. Influence of different strains of lactic acid bacteria on the growth of Propionibacterium freudenreichii KM in control whey. (a) Strains of Lactobacillus helveticus and Lb acidophilus; (b) Lb lactis; (c) strains of Streptococcus thermophilus; (d) strains of Lactococcus lactis.

Influence de différentes bactéries lactiques sur la croissance de Propionibacterium freudenreichii KM sur lactosérum. (a) Souches de Lactobacillus helveticus et Lb acidophilus; (b) Lb lactis; (c) souches de Streptococcus thermophilus; (d) souches de Lactococcus lactis.

cell mass, but to varying extents. The largest increases were observed with the Lactobacillus strains which increased growth rates by up to $17 \%$ and more than doubled the final cell mass. On the other hand, Str thermophilus strains had only a small effect on the growth rate ( $6 \%$ increase) but increased the cell mass significantly: a 2.2-fold increase was observed with strain STB01.
The interactions between the other strains of $P A B$ and $L A B$ varied (table I). Each of the 4 strains of $P A B$ used were stimulated by $L b$ helveticus and Str thermophilus STB01. Some $P A B / L A B$ pairs showed no interaction (eg $P A B$ strain $T$ was not affected by Str thermophilus 1781 and STB02 nor by the Lactococcus lactis strains) (table I). At the end of these preliminary experiments, 
Table I. Percentage increase in final biomass production $\left(\mathrm{OD}_{600}\right)$ of 4 strains of propionic acid bacteria (PAB) after growth for $72 \mathrm{~h}$ in lactic acid bacteria (LAB) wheys compared with control wheys.

Pourcentage d'augmentation de la production finale de biomasse $\left(D O_{600}\right)$ de 4 souches de propionibactéries après $72 \mathrm{~h}$ de croissance dans le lactosérum produit par les bactéries lactiques comparé au lactosérum témoin.

\begin{tabular}{|c|c|c|c|c|c|}
\hline \multirow[t]{2}{*}{$\angle A B$} & & \multicolumn{4}{|c|}{ Propionibacterium } \\
\hline & & $\angle 5$ & $T$ & $K M$ & $H$ \\
\hline \multirow[t]{3}{*}{ Lactobacillus helveticus } & RR & 249 & 174 & 112 & 384 \\
\hline & 303 & 173 & 151 & 128 & 48 \\
\hline & 3321 & 247 & 218 & 144 & 35 \\
\hline Lactobacillus acidophilus & LbA & 0 & 201 & 137 & 35 \\
\hline $\begin{array}{l}\text { Lactobacillus delbrueckii } \\
\text { subsp lactis }\end{array}$ & LL51 & 0 & 51 & 194 & 0 \\
\hline \multirow[t]{5}{*}{ Streptococcus thermophilus } & 1781 & 77 & 0 & 116 & 33 \\
\hline & 1821 & 0 & 155 & 98 & 33 \\
\hline & 1842 & 0 & 136 & 117 & 53 \\
\hline & STB01 & 166 & 112 & 126 & 52 \\
\hline & STB02 & 51 & 0 & 107 & 34 \\
\hline \multirow[t]{3}{*}{ Lactococcus lactis } & $\mathrm{C} 10$ & 212 & 0 & 159 & 35 \\
\hline & ML8 & 244 & 0 & 137 & 60 \\
\hline & AM2 & 173 & 0 & 51 & 34 \\
\hline
\end{tabular}

Lactobacillus helveticus RR and Propionibacterium freudenreichii KM were selected for more detailed studies, because all strains of PAB were stimulated by Lactobacillus helveticus RR and all strains of $L A B$, except Lc lactis E8, stimulated $P$ freudenreichii KM.

\section{Influence of milk on stimulation}

Control and starter wheys were produced from 2 skim milk powders and a sample of pasteurized skim milk. The stimulation of $P$ freudenreichii KM by $L b$ helveticus RR occurred regardless of the milk in which it was grown (data not shown).

\section{Growth and fermentation in control whey}

In experiments carried out in control whey, lactose was never used by $P$ freudenreichii $\mathrm{KM}$ during the fermentation (fig 2a); at the end of fermentation, the culture reached an $\mathrm{OD}_{600}$ of $\sim 0.60$ and the $\mathrm{pH}$ decreased to 5.85. Similar results were obtained for the other 3 strains of PAB. Lactate utilization was slow during the first $24 \mathrm{~h}$ of growth after which $L$ lactate was used preferentially over D lactate (fig 2a). At the end of growth, 8.3 $\mathrm{mmol} / \mathrm{l}$ of L lactate and $42.1 \mathrm{mmol} / \mathrm{l}$ of $\mathrm{D}$ lactate remained in the whey, corresponding to an overall utilization of $82 \%$ of the L lactate and $12 \%$ of the D lactate. Propionate 

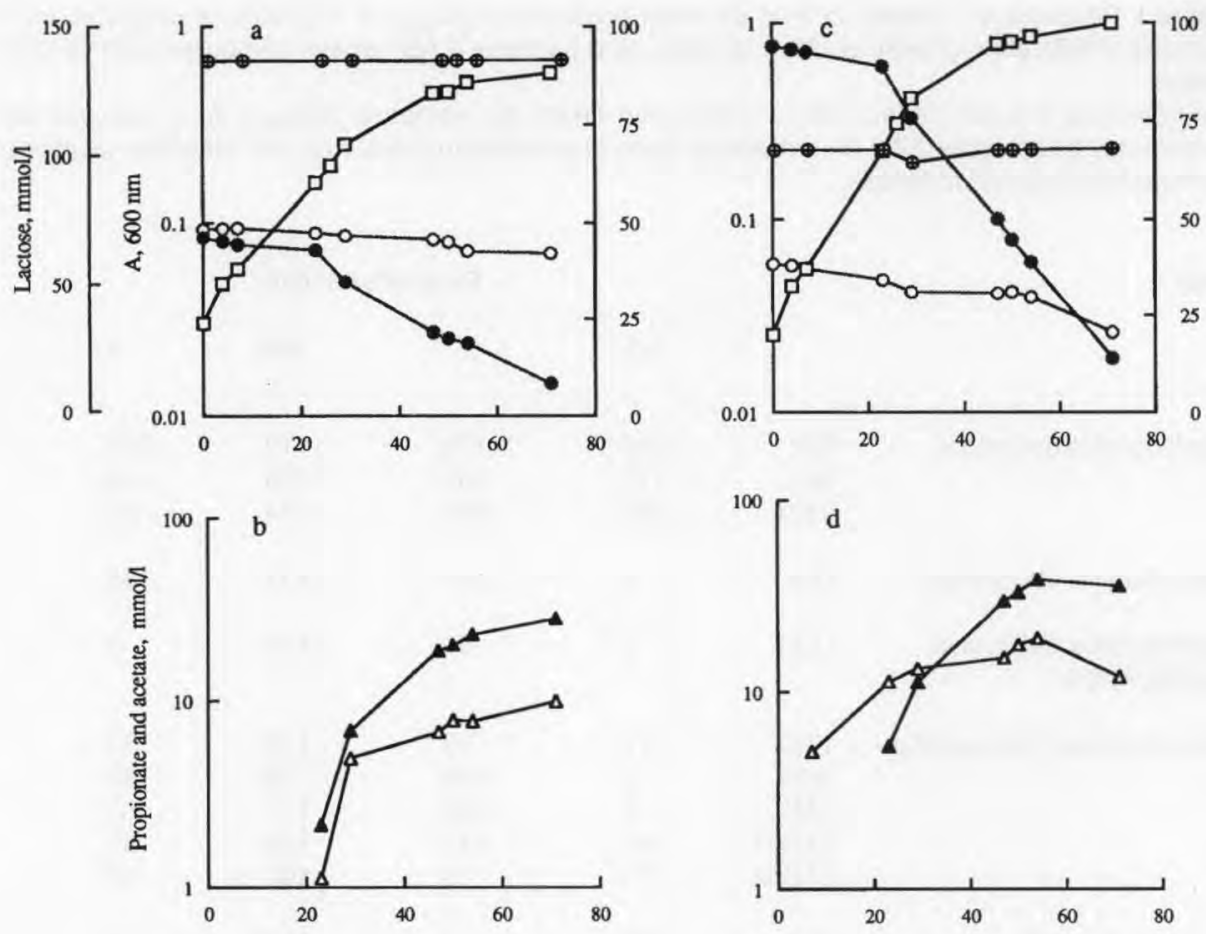

Time, $\mathrm{h}$

Time, h

Fig 2. Growth, substrate utilization and product formation by Propionibacterium freudenreichii KM in $(\mathbf{a}, \mathbf{b})$ control whey and (c, d) Lactobacillus helveticus RR whey. ( $\square$ ) growth; $(\bigcirc)$ D lactate utilization; $(\bullet)$ L lactate utilization; $(\Theta)$ lactose utilization; $(\mathbf{\Delta})$ propionate production; $(\Delta)$ acetate production. Croissance, utilisation des substrats et formation des produits de la fermentation par Propionibacterium freudenreichii $K M$ sur $(\boldsymbol{a}, \boldsymbol{b})$ lactosérum témoin et $(\boldsymbol{c}, \boldsymbol{d})$ lactosérum produit par Lactobacillus helveticus $R R$. $(\square)$ croissance; $(\bigcirc)$ utilisation du lactate $D$; $(\bullet)$ utilisation du lactate $L$; $(\oplus)$ utilisation du lactose; $(\mathbf{\Delta})$ production de propionate; $(\Delta)$ production d'acétate.

and acetate were only detected late in the fermentations, after $20 \mathrm{~h}$, and the combined production of propionate and acetate was stoichiometrically related to the disappearence of lactate (fig $2 b$ ); the molar ratios of propionate:lactate and acetate:lactate were 0.70 and 0.24 , respectively, and the correlation coefficients between propionate produced and lactate used and between acetate produced and lactate used were 0.99 and 0.95 , respectively. Succinate was not detected.

\section{Growth and fermentation in Lb helveticus RR whey}

Figure 2c shows the growth of $P$ freudenreichii KM in Lb helveticus RR whey. The culture attained a final OD of $\sim 0.99$, giving an increase in biomass of $70 \%$ compared to that in the control whey. The $\mathrm{pH}$ decreased from 6.0 to 5.8. As in the control whey, lactose was not utilized. Lactate utilization was slow for the first $24 \mathrm{~h}$ and again $\mathrm{L}$ lactate was used preferentially over D lactate (fig 
2c). By the end of the fermentation, $85 \%$ of the $L$ lactate and $46 \%$ of the $D$ lactate were metabolized and $36.0 \mathrm{mmol} / \mathrm{l}$ propionate and $19.0 \mathrm{mmol} / \mathrm{l}$ acetate were produced (fig $2 \mathrm{~d}$ ). The molar ratios between propionate and lactate and acetate and lactate were 0.61 and 0.23 , respectively; the correlation coefficients between propionate and lactate and acetate and lactate were 0.99 and 0.82 , respectively. Succinate $(13.3 \mathrm{mmol} / \mathrm{l})$ was detected, but only after $71 \mathrm{~h}$ of fermentation.
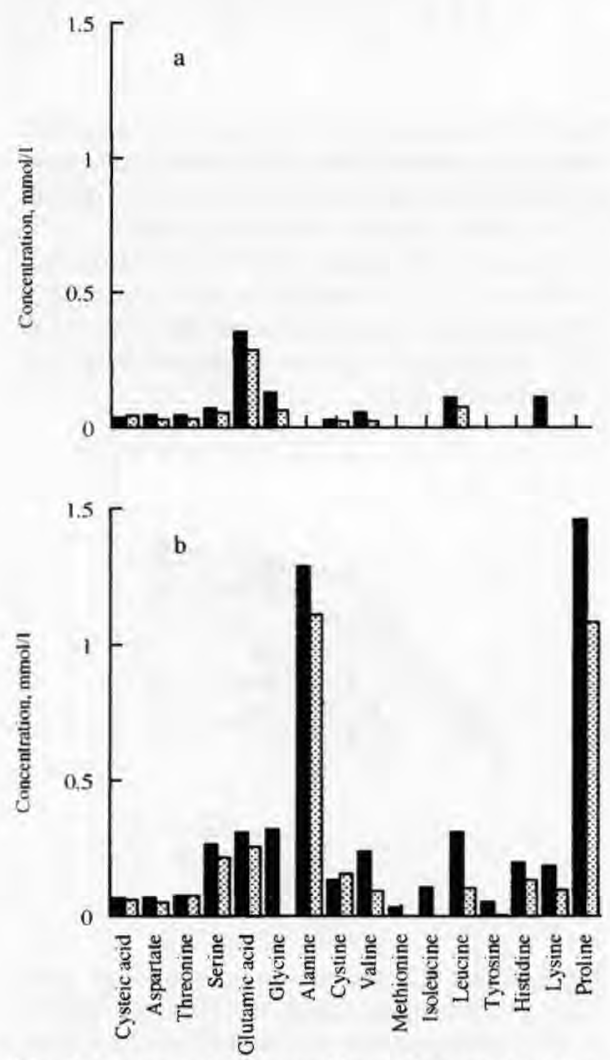

Fig 3. Amino acid composition of (a) control whey and (b) Lactobacillus helveticus RR whey at (ש) $\mathrm{O} \mathrm{h}$ and (国) after $41 \mathrm{~h}$ of growth of Propionibacterium freudenreichii $\mathrm{KM}$.

Composition en acides aminés du (a) lactosérum témoin et (b) lactosérum produit par Lactobacillus helveticus RR à (日) $0 \mathrm{~h}$ et (橉) après $41 \mathrm{~h}$ de croissance de Propionibacterium freudenreichii KM.

\section{Changes in amino acid composition of whey during fermentation}

The free amino acid composition of control and RR wheys are shown in figure 3 . Arginine and phenylalanine were not detected in either whey. Some amino acids (eg alanine, methionine, isoleucine, tyrosine, histidine and proline), which were not found in the control whey, were present in RR whey. In addition, the concentrations of some of the other amino acids (serine, alanine, cysteine, valine and leucine) in control whey were increased by the growth of strain RR. Glutamate was not increased by the growth of strain RR. All free amino acids, except threonine and cysteine, were utilized during subsequent growth of $P$ freudenreichii $\mathrm{KM}$ in starter whey. In order to verify if these differences in amino acid composition could explain the stimulation, growth in amino acid supplemented control whey was studied.

The addition of $0.1 \%$ and $1 \%$ vitamin free, acid-hydrolysed casein to control whey resulted in increased growth rates and cell yields of strain KM (fig 4), whereas the addition of $10 \%$ resulted in an inhibitory effect on growth rate but a stimulatory effect on cell yield. In addition to propionate and acetate (data not shown), succinate was produced during fermentation. The amount of succinate increased in direct proportion to the casein hydrolysate added and none was produced in the absence of casein hydrolysate. Several amino acids - aspartate (initial concentration $3.6 \mathrm{mmol} / \mathrm{l}$ ), serine $(1.4 \mathrm{mmol} / \mathrm{l})$, glycine $(1.2 \mathrm{mmol} / \mathrm{l})$ and alanine $(1.3 \mathrm{mmol} / \mathrm{l})$ - were utilized completely during the fermentation (fig 5 ). The addition of $1.5 \mathrm{mmol} / \mathrm{l}$ aspartate to control whey had no influence on the growth of KM (fig 6), but higher concentrations increased both the growth rate and growth yield. The amount of lactate metabolized and propionate and acetate produced also increased with increasing aspartate addition; succinate was produced but only in the presence 


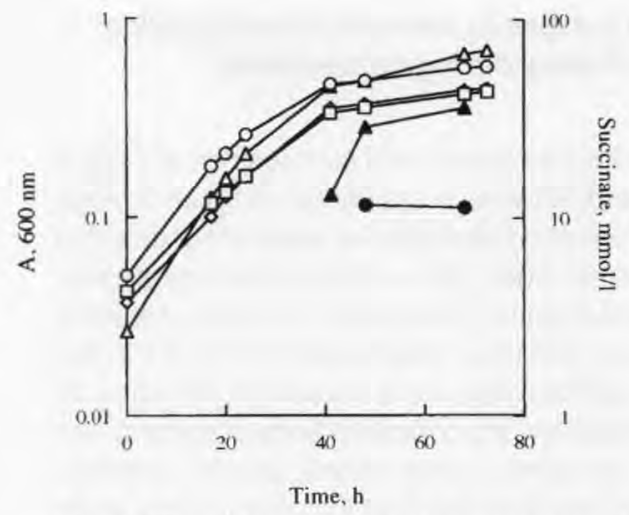

Fig 4. Effect of casein hydrolysate on growth (open symbols) and succinate production (closed symbols) of Propionibacterium freudenreichii KM. (D) $0.0 \%$ casein hydrolysate; $(\theta, 0) 0.1 \%$ casein hydrolysate; $(O, \bullet) 1.0 \%$ casein hydrolysate; $(\Delta, \mathbf{\Delta})$ $10 \%$ casein hydrolysate. Succinate was not produced in the absence of casein hydrolysate.

Effet d'un hydrolysat de caséine sur la croissance (symboles ouverts) et sur la production de succinate (symboles pleins) de Propionibacterium freudenreichii $K M$. (J) 0,0\% d'hydrolysat de caséine; $(0, \bullet) 0,1 \%$ d'hydrolysat de caséine; $(0,0) 1,0 \%$ d'hydrolysat de caséine; $(\Delta, \mathbf{\Delta}) 10 \%$ d'hydrolysat de caséine. Le succinate n'était pas produit en absence d'hydrolysat de caséine.

of 6 and $30 \mathrm{mmol} / \mathrm{l}$ aspartate (fig 6 ). The molar ratios of propionate:lactate were 0.71 , $0.65,0.59$ and 0.53 in the presence of 0 , $1.5,6$ and $30 \mathrm{mmol} / \mathrm{l}$ aspartate, respectively. The molar ratios of acetate:lactate did not change significantly with increasing levels of aspartate. No effects were observed on addition of up to $30 \mathrm{mmol} / \mathrm{l}$ each of alanine, serine or glycine, both individually or together (data not shown).

\section{Changes in peptide composition during fermentation}

In addition to amino acids, RR whey also had higher concentrations of peptides than control whey (fig 7). Most of the peptides in

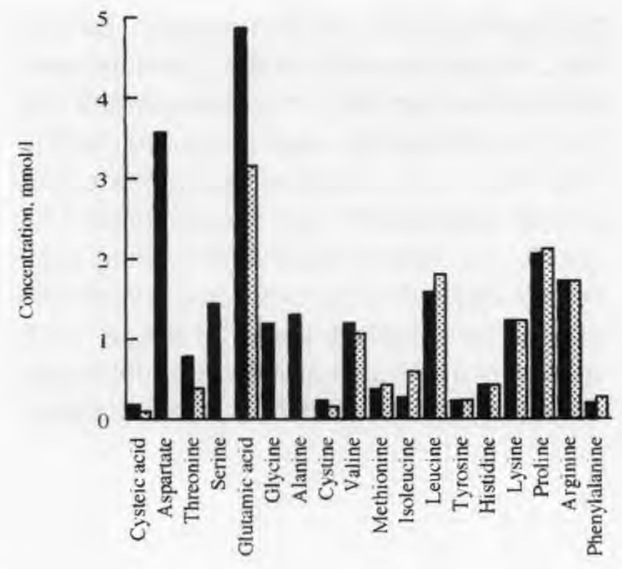

Fig 5. Free amino acid composition of control whey supplemented with $1.0 \%$ casein hydrolysate at the beginning ( $\mathbf{D})$ and at the end $(\square)$ of growth of Propionibacterium freudenreichii KM.

Composition en acides aminés libres du lactosérum témoin supplémenté avec 1,0\% d'hydrolysat de caséine en début (1) et fin (71 h) () de fermentation par Propionibacterium freudenreichii $K M$.

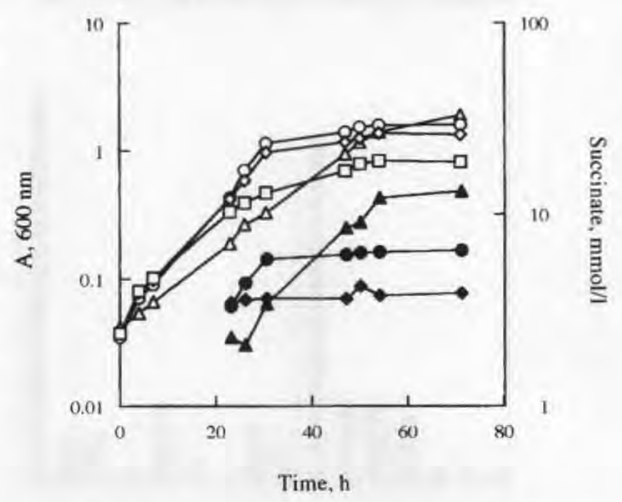

Fig 6. Effect of aspartate on growth (open symbols) and succinate production (closed symbols) of Propionibacterium freudenreichii KM in control whey. ( $\square) 0.0 \mathrm{mmol} / \mathrm{l}$ aspartate; $(0) 1.5 \mathrm{mmol} / \mathrm{l}$ aspartate; $(\mathrm{O}, \bullet) 6.0 \mathrm{mmol} / \mathrm{l}$ aspartate; $(\Delta, \mathbf{\Delta}) 30$ $\mathrm{mmol} / \mathrm{l}$ aspartate.

Effet de l'aspartate sur la croissance (symboles ouverts) et sur la production de succinate (symboles pleins) de Propionibacterium freudenreichii $K M$ sur lactosérum témoin. (a) $0,0 \mathrm{mmol} / \mathrm{l}$ d'aspartate; ( $(0)$ 1,5 mmol/ d'aspartate; $(0, \bullet)$ 6,0 mmol/l d'aspartate; $(\Delta, \mathbf{\Delta}) 30 \mathrm{mmol} / \mathrm{l}$ d'aspartate. 
the RR whey were utilized during subsequent growth of $P$ freudenreichii $\mathrm{KM}$, regardless of their hydrophobicities (fig 8). Some peptides were higher in concentration after

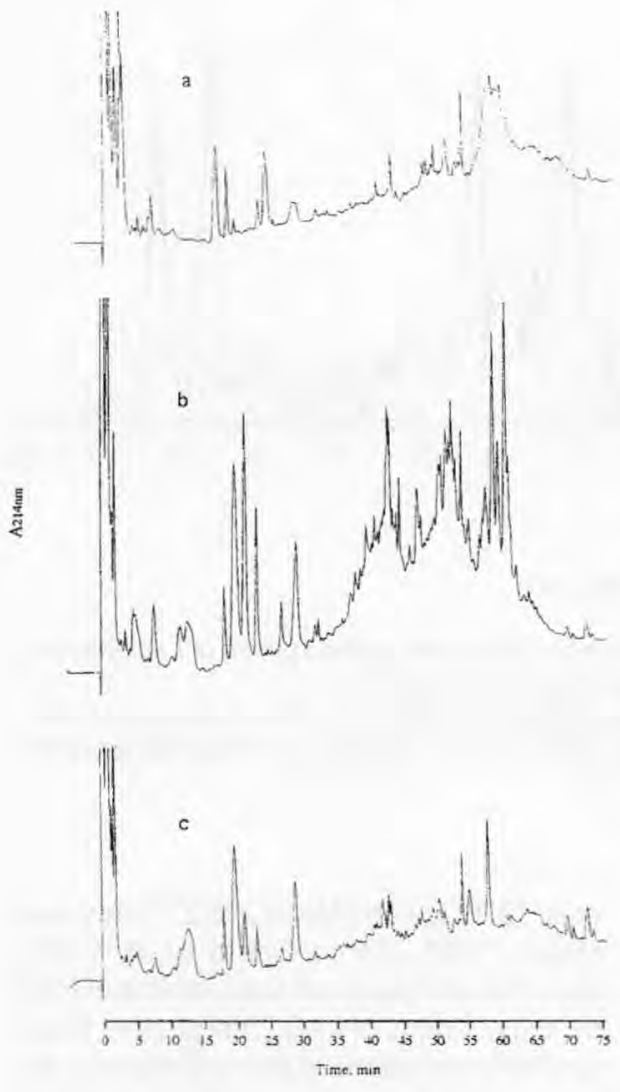

Fig 7. Peptide profiles of (a) control whey before growth of Propionibacterium freudenreichii KM, (b) Lactobacillus helveticus RR whey before growth of Propionibacterium freudenreichii KM and (c) Lactobacillus helveticus RR whey after ultrafiltration.

Profiles peptidiques du (a) lactosérum témoin avant croissance de Propionibacterium freudenreichii $K M$, (b) lactosérum produit par Lactobacillus helveticus $R R$, avant croissance de Propionibacterium freudenreichii $K M$ et (c) lactosérum de Lactobacillus helveticus $R R$ ayant subi une ultrafiltration. growth of the PAB, which may be due to production of peptides by the PAB during growth or to hydrolysis of some peptides into smaller ones, which elute at different times, but which are not used or used only to a limited extent by the PAB.

\section{Ultrafiltration}

Ultrafiltration of RR whey was used in an attempt to determine whether the stimulant(s) was a high or low molecular mass compound(s). After ultrafiltration of RR whey, KM did not grow in either the retentate, permeate or in the recombined permeate plus retentate. Ultrafiltration resulted in a dramatic reduction of the peptides of the recombined permeate and retentate (fig 7); some peptides were missing and some were present but at a much lower concentration.

\section{Influence of heat treatment on the stimulant(s)}

Pasteurization and autoclaving of RR whey resulted in a precipitate which was removed by centrifugation before filtering and filter sterilizing the supernatant. These heat treatments did not affect the rates of growth of strain $\mathrm{KM}$, but a slightly reduced final cell mass was obtained in the case of autoclaved whey (data not shown).

\section{Effect of perchloric acid extraction on the stimulant(s)}

Treatment with perchloric acid precipitated the proteins from the whey. This procedure caused a 2.5-fold dilution of the whey, but stimulation was still observed in it compared with a control whey which had also been diluted 2.5-fold (data not shown). 


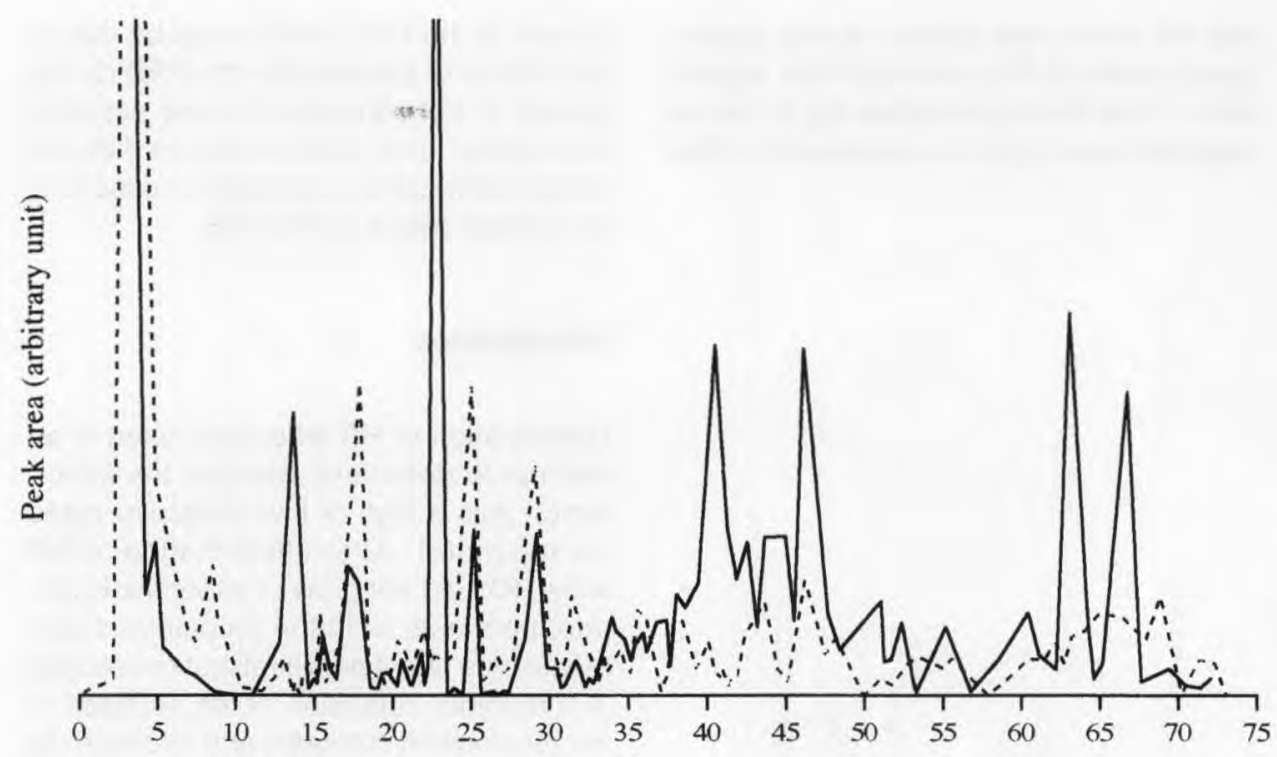

Time, $\min$

Fig 8. Effect of growth of Propionibacterium freudenreichii KM on the peptide profile of Lactobacillus helveticus RR whey. Solid line, before growth; broken line, after growth.

Modifications du profile peptidique du lactosérum de Lactobacillus helveticus $R R$, induites par la croissance de Propionibacterium freudenreichii KM. Lignes pleines, avant croissance; lignes pointillées, après croissance.

\section{Partial isolation of the stimulant(s) by gel filtration}

The gel-filtration profile of RR whey, after separation on Sephadex G25, is shown in figure 9 . Eleven different peaks were obtained and peaks 1 to 4 contained most of the stimulatory activity. These results suggest that several stimulants are involved with molecular masses of less than 5000 Da.

\section{DISCUSSION}

Earlier workers (Hunter and Frazier, 1961; Czarnocka-Roczniakowa et al, 1972; Lee et al, 1976; Liu and Moon, 1982; Parker and Moon, 1982; Perez Chaia et al, 1987) observed stimulation of some strains of PAB by some strains of $L A B$. The present study confirms the ability of several starter $L A B$ to stimulate the growth of PAB in wheys, in that 13 of 14 strains of LAB tested stimulated growth of 1 or more of 4 strains of $\mathrm{PAB}$. The stimulatory activity of $\mathrm{Lb}$ acidophilus and $L b$ lactis depended on the strain of PAB used. Similar results were obtained by Liu and Moon (1982) and Parker and Moon (1982). The stimulatory activity of Lactococcus lactis depended, on the one hand, on the strain used (strain E8 had no effect) and on the other hand, on the PAB strain used (no stimulation by any of the 4 strains tested was observed with 
$P A B$ strain $T$ ). This variation of the stimulation according to the $P A B$ strain used was noted by Czarnocka-Roczniakowa et al (1972), but the stimulation was low. The latter workers also found that Str thermophilus T149 stimulated the growth of 3 strains of PAB. In the present study, all 5 strains of Str thermophilus stimulated $\mathrm{PAB}$ strains $\mathrm{KM}$ and $\mathrm{H}$. However, for PAB strains $\mathrm{L} 5$ and $T$, the stimulation depended on the strain of
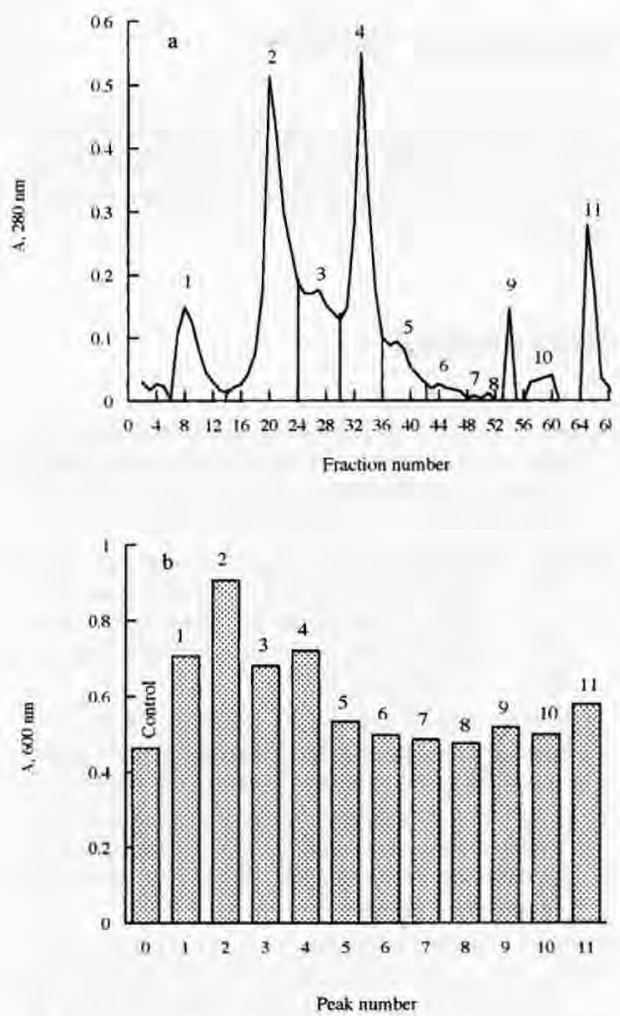

Fig 9. Separation of Lactobacillus helveticus RR whey on Sephadex G-25. (a) Chromatogram; (b) biomass $\left(A_{600}\right)$ of Propionibacterium freudenreichii $\mathrm{KM}$ in control whey supplemented with material from the different fractions.

Séparation du lactosérum de Lactobacillus helveticus RR sur Sephadex G-25. (a) Chromatogramme ; (b) biomasse $\left(A_{600}\right)$ de Propionibacterium freudenreichii $K M$ dans le lactosérum témoin et dans le lactosérum témoin supplémenté avec les différentes fractions.
Str thermophilus used. In the present work, $L b$ helveticus strains were the most consistent stimulators, in that the 3 strains used stimulated the 4 PAB strains studied. Such stimulation has also been reported previously by Czarnocka-Roczniakowa et al (1972) and Perez Chaia et al (1987).

The more detailed study of the stimulation of $P$ freudenreichii $\mathrm{KM}$ by $L b$ helveticus RR showed that the increase in growth rate and cell yield coincided with an increased conversion of lactate to propionate and acetate (fig 2). L lactate was used faster than D lactate in both starter and control whey, in agreement with previous data of Crow (1986a). All strains of PAB used in this study metabolize lactose, but lactose was not utilized during growth in whey containing lactate which was still present when growth ceased. Marcoux et al (1992) observed lactose utilization by PAB in wheybased media containing lactose, lactate and yeast extract, but only when most of the lactate had been metabolized.

Amino acids are metabolized by PAB in the presence of lactate (fig 3 ). In a mixture of amino acids (vitamin-free, acid-hydrolysed casein), aspartate, serine, glycine, alanine and glutamic acid were mainly metabolized (fig 5). These results are in agreement with those of Brendehaug and Langsrud (1985). Crow (1986b) showed that aspartate, alanine and serine were used by PAB, but aspartate appeared to be the only one readily metabolized in a Swiss-type cheese environment. Of the 4 main free amino acids used by $P A B$ in this study, aspartate was the only one found to stimulate strain KM (fig 6). However, the concentration of free aspartate was less than $0.1 \mathrm{mmol} / \mathrm{l}$ in starter and control wheys. In control whey, free aspartate concentrations greater than 15 times the concentration found in the starter whey were needed to stimulate the growth of KM. Succinate was detected during growth in control whey supplemented with aspartate or casein hydrolysate. This coin- 
cided with a decrease in the ratio of propionate:acetate formed from lactate. Crow (1986b) reported similar findings. In the present study, the amount of succinate detected at the end of fermentation was $5 \mathrm{mmol} / \mathrm{l}$ greater than the amount of aspartate used. Crow (1986b) proposed that the additional succinate was formed from pyruvate in a pathway involving $\mathrm{CO}_{2}$ fixation and oxaloacetate production. $\mathrm{CO}_{2}$ was not measured in the present study.

The stimulatory compound(s) was resistant to pasteurization and autoclaving and stable to precipitation with perchloric acid. These results agree with those of Hunter and Frazier (1961) but contrast with those of Czarnocka-Roczniakowa et al (1972), who reported a decrease of stimulatory activity after pasteurization. Attempts were made to determine the molecular mass. Ultrafiltration was useless because of absorption of the stimulant(s) on the membrane. Gel filtration with Sephadex G25 suggests that the molecular mass is less than $5000 \mathrm{Da}$, since most of the activity eluted after the void volume. These results also suggest that several compounds are involved since stimulatory activity was present in several peaks. However, since water was used as eluent, nonspecific adsorbtion of one particular compound to the column may result in the compound eluting in several peaks. Such interactions can be reduced by elution with $\mathrm{NaCl}$ which increases the ionic strength. However, $\mathrm{NaCl}$ could not be used here because of the inhibitory activity of salt on the growth of PAB (Hettinga and Reinbold, 1972).

The production of high levels of amino acids and peptides by LAB in milk and cheese is not unusual (Accolas et al, 1980; Desmazeaud, 1983). Lb helveticus RR produced free amino acids and peptides, some of which were utilized during growth of strain KM. PAB have intracellular (Perez Chaia et al, 1990; El-Soda et al, 1992) and extracellular peptide hydrolase activities (Langsrud et al, 1977). Peptide utilization has been reported during Swiss-type cheese ripening where late fermentation was linked to an increased breakdown of some peptides with molecular masses around 3000 (Blanc et al, 1979). Although the concentration of free aspartate in starter whey was too low to account for the stimulation observed, it is possible that aspartate is responsible for the stimulation as a constituent of a peptide.

\section{ACKNOWLEDGMENTS}

This research was partly funded by the European Union through the Structural Fund Programme. PGP thanks Teagasc for the award of a studentship.

\section{REFERENCES}

Accolas JP, Hemme D, Desmazeaud MJ, Vassal L, Bouillanne C, Veaux M (1980) Les levains lactiques thermophiles : propriétés et comportement en technologie laitière. Lait 60, 487-524

Blanc B, Ruegg M, Baer A, Casey M, Lukesch A (1979) Essais comparatifs dans le fromage d'emmental avec et sans fermentation secondaire. IV. Comparaison biochimique et physico-chimique. Schweiz Milchw Forschung 8, 27-36

Brendehaug J, Langsrud T (1985) Amino acid metabolism in propionibacteria: resting cells experiments with four strains. J Dairy Sci 68, 281-289

Crow VL (1986a) Utilization of lactate isomers by Pro. pionibacterium freudenreichii subsp shermanit: regulatory role of intracellular pyruvate. App/ Environ Microbiol 52, 352-358

Crow VL (1986b) Metabolism of aspartate by Propionibacterium freudenreichii subsp shermanii: effect on lactate fermentation. Appl Environ Microbio/ 52, 359365

Czarnocka-Roczniakowa B, Jaworski J, Kornacka D (1972) Effet stimulant de la microflore lactique sur l'activité biochimique des bactéries propioniques. Lait 52, 193-202

Desmazeaud M (1983) L'état des connaissances en matière de nutrition des bactéries lactiques. Lait 63 , 267-316

El-Soda M, Zlada N, Ezzat N (1992) The intracellular peptide-hydrolase system of Propionibacterium. Microbios 72, 65-74 
Gautier M, Lortal S, Boyaval P, Girard F, Lemée R, de Carvalho AF, Dupuis C (1993) Les bactéries propioniques laitières. Lait 73, 257-263

Hettinga DH, Reinbold GW (1972) The propionic acid bacteria, a review. J Milk Food Technol 35, 295301, 358-372, 436-447

Hunter JE, Frazier WC (1961) Gas production by associated Swiss cheese bacteria. J Dairy Sci 44, 2176-2186

Langsrud T, Reinbold GW (1973) Flavor development and microbiology of Swiss cheese: a review. J Milk Food Technol 36, 531-542, 593-609

Langsrud T, Reinbold GW, Hammond EG (1977) Proline production by Propionibacterium shermanii P59. J Dairy Sci 60, 16-23

Lee IH, Fredrickson AG, Tsuchiya HM (1976) Dynamics of mixed cultures of Lactobacillus plantarum and Propionibacterium shermanii. Biotechnol Bioeng 18, 513-526
Liu JAP, Moon J (1982) Commensalistic interaction between Lactobacillus acidophilus and Propionibacterium shermanii subsp shermanii. Appl Environ Microbiol 44, 715-722

Marcoux V, Beaulieu Y, Champagne CP, Goulet J (1992) Production of Propionibacterium freudenreichii subsp shermanii in whey-based media. J Ferment Bioeng $74,95-99$

Parker JA, Moon NJ (1982) Interactions of Lactobacillus and Propionibacterium in mixed cultures. J Food Prot 45, 326-330

Perez Chaia A, Ruiz Holgado AP, Oliver G (1987) Interaction between Lactobacillus helveticus and Propionibacterium freudenreichii subsp shermanii. Microbiol Aliment Nutr 5, 325-331

Perez Chaia A, Ruiz Holgado AP, Oliver G (1990) Peptide hydrolases of propionibacteria: effect of $\mathrm{pH}$ and temperature. J Food Prot 53, 237-240 